Sidorela Vishkulli*, Nereida Dalanaj, Ilirjana Boci, Sonila Vito, Aldi Kuqo

University of Tirana, Department of Industrial Chemistry, Faculty of Natural Sciences, Tirana, Albania
Scientific paper

ISSN 0351-9465, E-ISSN 2466-2585

UDC: $667.622 .2: 669.227-492.2(\mathrm{n})$

doi:10.5937/zasmat1804529V

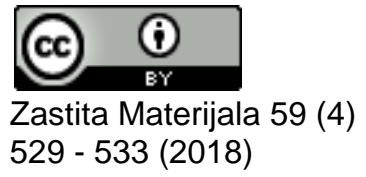

\title{
Investigation of the efficiency of silver nanoparticles suspension in paints of indoor environment
}

\begin{abstract}
Over the last few decades, nanoparticles of metals have been attracted attention for the wide range of applications in various fields of industry, especially Ag nanoparticles which have been used for their biocidal properties. On the other hand painting is practiced since in ancient times for decoration, but the paint surfaces undergo damage due to natural weathering and the growth and activity of living organisms. Various types of organisms are involved in paint spoilage, such as bacteria, algae and fungi. To prevent paints from biodeterioriation are used biocide substances, which with time have caused environmental and health problems. In this experimental work we aimed to investigate the antifungal efficiency of silver nanoparticles compared to a trade biocide substance sold in our market for paints of indoor environment. A series of microbiological tests were carried out. The results obtained showed that $\mathrm{Ag}$ nanoparticles are effective in inhibition of fungal growth.
\end{abstract}

Keywords: paints, mycological resistance, Ag nanoparticles.

\section{INTRODUCTION}

Paints are used to decorate, protect and prolong the life of natural and synthetic materials, and act as a barrier against environmental conditions. But due to weather and environmental conditions they undergo damage and thus rise the risk for health hazards for inhabitants [1].

Microorganisms are also known for their potential to degrade synthetic compounds. Various microbial species are reported for paint degradation. Major groups of microbes involved in paints degradation are bacteria and fungi. Various fungi, e.g., species of Penicillium, Aspergillus, Cladosporium, Chaetomium, and Alternaria are reported to play a vital role in such degradative processes [2,3].

Paint's deterioration on surfaces or in the environment causes its components to be mineralized. This corrosion on the surface is not only an

\footnotetext{
${ }^{*}$ Corresponding author: Sidorela Vishkulli

E-mail: sidorela.vishkulli@fshn.edu.al

Paper received: 24. 10. 2018.

Paper accepted: 07. 11. 2018.

Paper is available on the website:

www.idk.org.rs/journal
}

economic loss, but also results in the release of harmful degradation products into the environment, causing an alarming situation. Although there are certain chemical approaches available for removal of degraded products, these methods have some disadvantages [2]. The use of biocide active substances which have been used for a long time, due to environmental concerns, nowadays is requested to avoid their application.

Silver nanoparticles (Ag-NPs or nanosilver) have attracted increasing interest due to their unique physical, chemical and biological properties. Compared to their macro-scaled counterparts AgNPs exhibit broad spectrum bactericidal and fungicidal activity that has made them extremely popular in a diverse range of consumer products, including plastics, soaps, pastes, food and textiles, increasing their market value. Recently, using nanosilver as a biological agent has become increasingly common [2, 3].

According to previous studies, silver nanoparticles have been reported to have excellent antimicrobial properties when they are used in paints and coatings [4]. 
In this work we have used silver nanoparticles produced by chemical method, in paints for indoor applications, in order to investigate their antifungal properties compared to a trade biocidal substance found in our market.

\section{EXPERIMENTAL}

\subsection{Drying process of raspberries}

The fresh raspberries were collected and dried naturally until constant weight, in order to prevent the chemical compounds from thermal degradation.

\subsection{Extraction of raspberries}

A weighted amount of dried raspberries $(4.5 \mathrm{~g})$ was ingrained into a flask with distilled water. The flask was placed in a water bath, in $30^{\circ} \mathrm{C}$ and the content was stirred for 5 minutes. In the end, the content was filtered to get the filtrate for further using.

\subsection{Preparation of silver nitrate solution}

We weighted the exact amount of solid silver nitrate $(0.0048 \mathrm{~g})$ and added it in a flask with distilled water. When the solid crystals of silver nitrate were soluted, we added distilled water to fill the flask until the sign, in order to obtain the required solution.

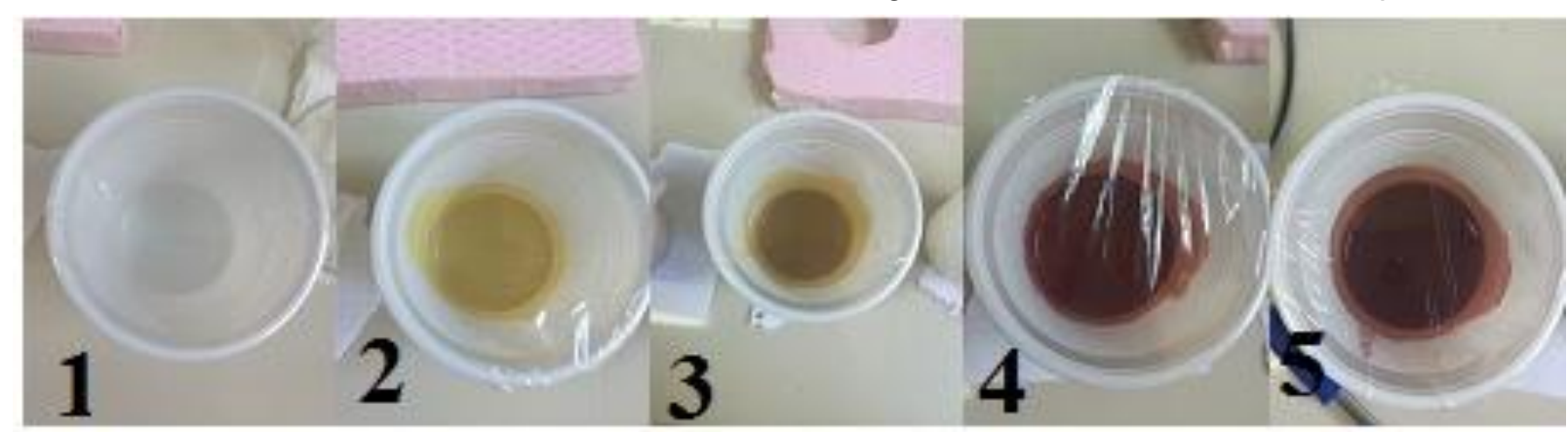

Figure 1. Homogenized samples

Slika 1. Homogenizovani uzorci

\subsection{Preparation of silver nanoparticles suspension}

For production of the suspension of silver nanoparticles, we used the chemical method. The prepared solution of silver nitrate was used as source for silver ions and the extract of raspberry as a reducing and stabilizing agent. $\mathrm{NaOH} 1 \mathrm{M}$ solution was used to adjust $\mathrm{pH}$ to 10 . The mixture was stirred on a magnetic stirrer for 5 minutes. The produced suspension was kept in plastic container to stand and then analysed with UV-VIS spectrophotometer to obtain his absorption spectra.

\subsection{Mycological investigation}

For studying the mycological efficacy of $\mathrm{Ag}$ nanoparticles, a series of three samples were prepared for each observation according to the table below. Aspergillus terreus was the fungus which was investigated in this experimental work.

As it can be seen by the table below, for this experimental work we prepared five different samples in order to compare the results. The samples differ from each other by the amount of $\mathrm{Ag}$ suspension and biocide substance added. For each case we prepared three parallel samples in order to obtain better results.

In figure 1 are presented all the samples with their components mixed together. The numbers in the figure refer to the numbers of sample to table 1 .

Table 1. Experimental matrix for mycological tests

Tabela 1. Eksperimentalna matrica za mikološke testove

\begin{tabular}{|c|c|c|c|c|}
\hline Sample & Paint $(\mathrm{g})$ & Fungus suspension $(\mathrm{ml})$ & Ag suspension $(\mathrm{ml})$ & Biocide substance $(\mathrm{g})$ \\
\hline 1 & 2 & 2 & - & 1 \\
\hline 2 & 2 & 2 & 5 & - \\
\hline 3 & 2 & 2 & 5 & - \\
\hline 4 & 2 & 2 & 8 & 1 \\
\hline 5 & 2 & 2 & & 1 \\
\hline
\end{tabular}




\section{RESULTS AND DISCUSSION}

The absorption spectra of raspberry extract and silver suspension are shown below (figure 2).

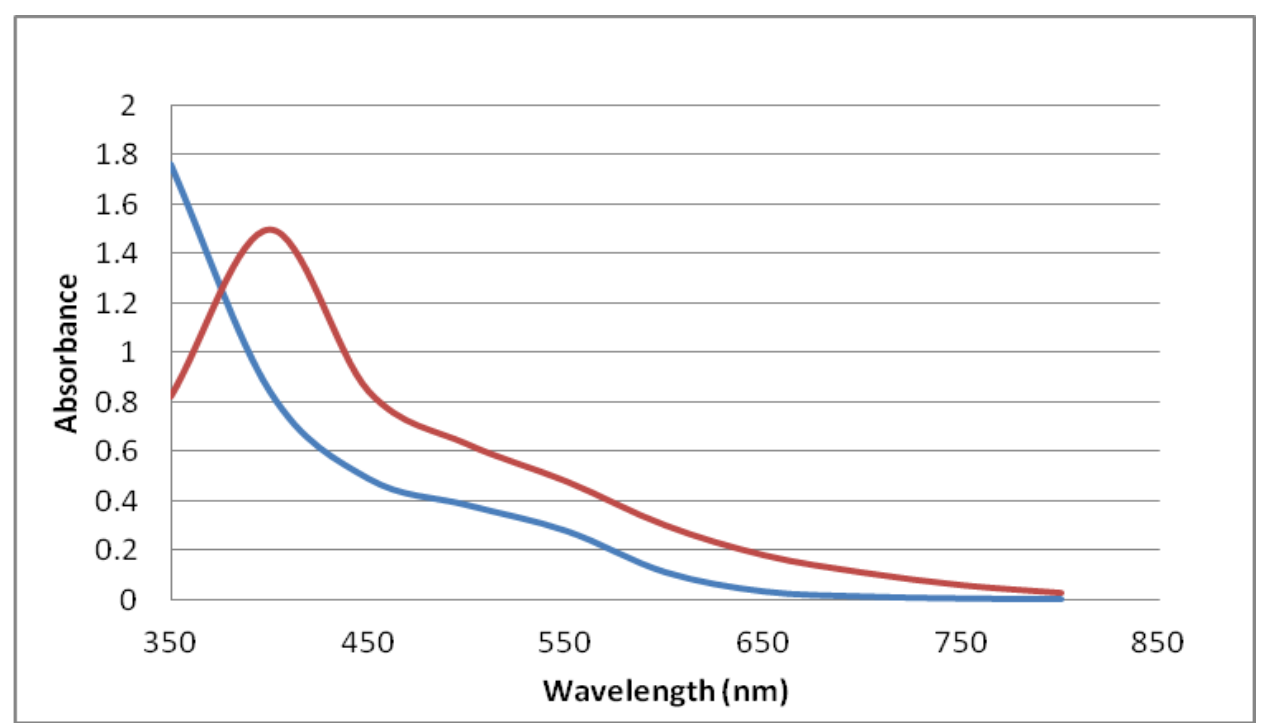

Figure 2 The absorption spectra of raspberry extract (blue line) and silver nanoparticles suspension (red line)

Slika 2. Spektri apsorpcije ekstrakta maline (plava linija) i suspenzije nanočestica srebra (crvena linija)

From the graph it can be seen that the maximum peak of absorption of silver nanoparticles is not overlapped with the maximum of extract, which means that they do not interferee in absorbance measurements in the production of silver suspension. The peak around 450nm corresponds to the characteristics surface Plasmon resonance of silver nanoparticles.

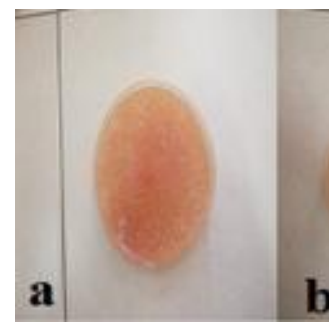

\subsection{Mycological investigation for all samples}

In figure 3 is presented only the fungus without any amount of biocide substance or Ag suspension added to plate of testing. As it is shown in the figure, fungus is grown better after 14 days of incubation, where it has filled nearly all the surface of the testing plate.

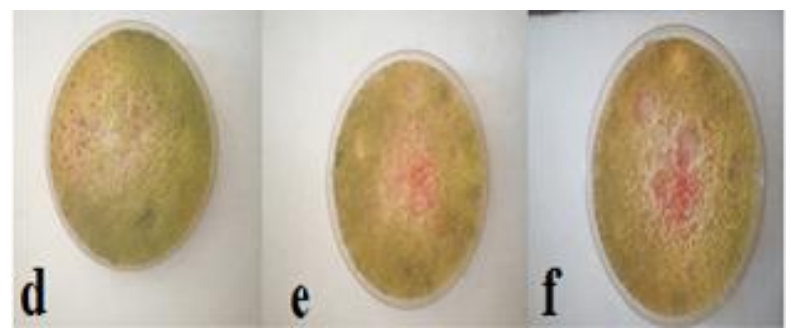

Figure 3. Fungus sample after 7 days $(a, b, c)$ and 14 days $(d, e, f)$

Slika 3. Uzoraci gljiva posle 7 dana $(a, b, c)$ i 14 dana $(d, e, f)$
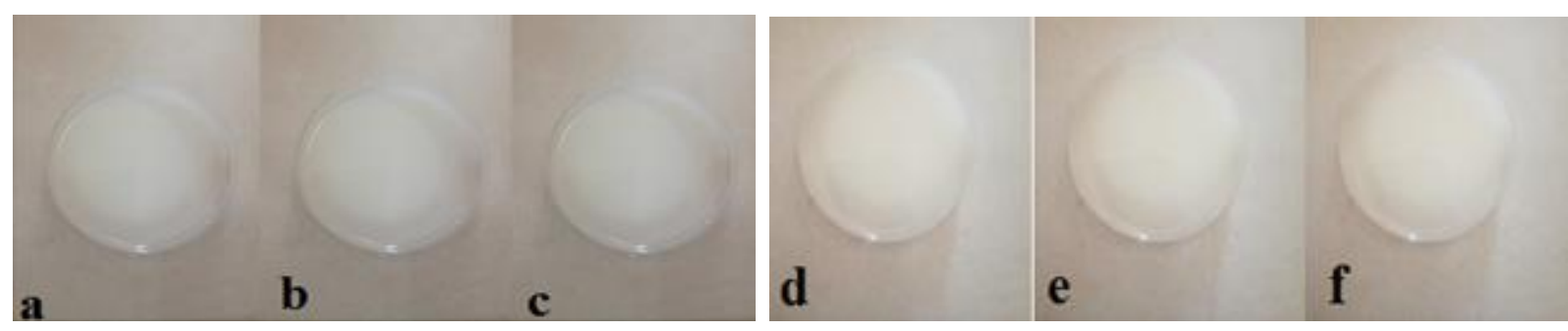

Figure 4. Sample 1 after 7 days $(a, b, c)$ and 14 days $(d, e, f)$

Slika 4. Uzorak 1 posle 7 dana $(a, b, c)$ i 14 dana $(d, e, f)$ 
From figures we can conclude that Ag nanoparticles suspension produced by us doesn't have the same efficiency as the trade biocidal substance when we added them in the same volume (fig. 4 and 5).
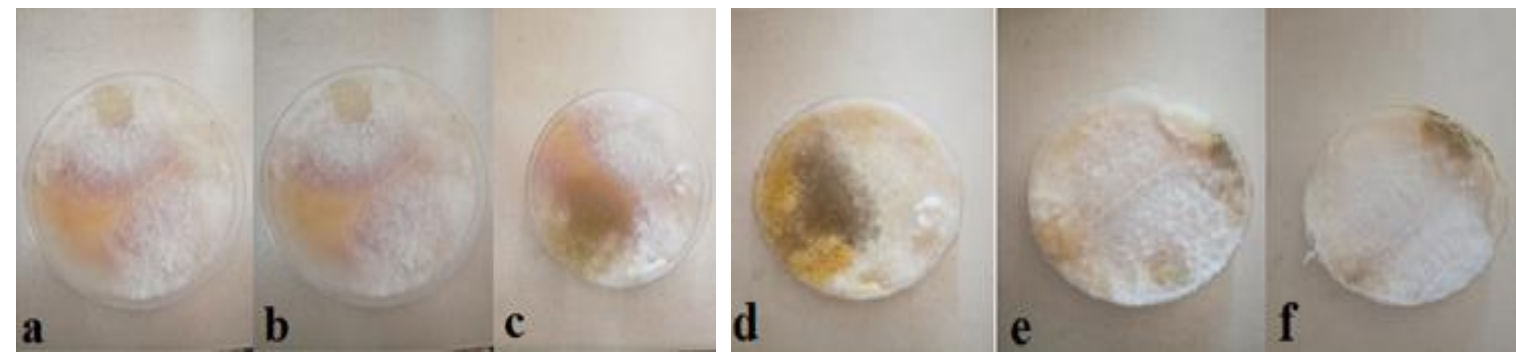

Figure 5. Sample 2 after 7 days (a, b, $c)$ and 14 days (d, e, f)

Slika 5. Uzorak 2 posle 7 dana $(a, b, c)$ i 14 dana $(d, e, f)$

From figure 5 , it can be seen that the fungus is grown nearly in all the plate surface, both after 7 and 14 days. But when we rise the volume of $\mathrm{Ag}$ nanoparticles suspension, then the antifungal effect is increased (fig. 5 and 6).
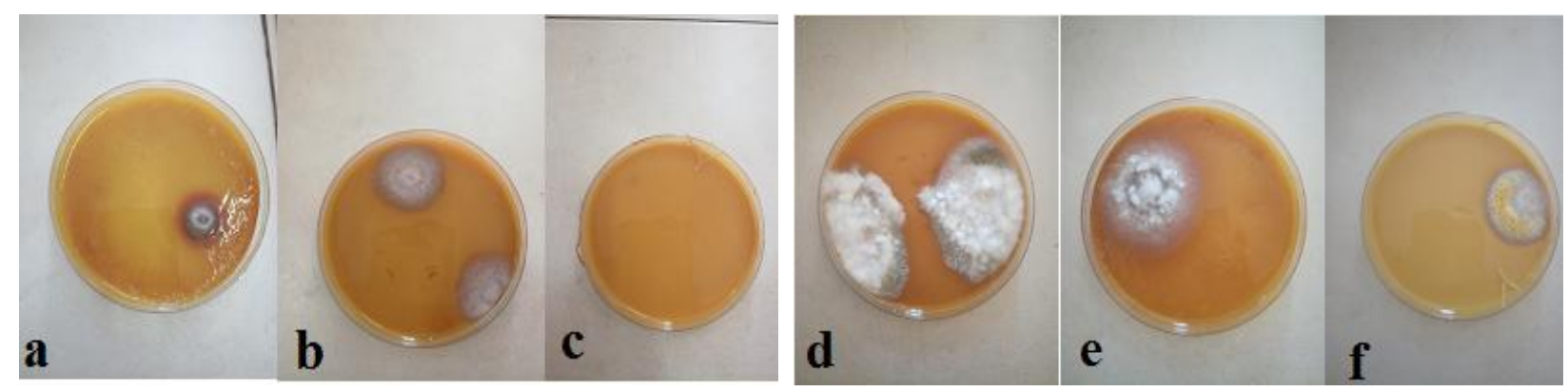

Figure 6 Sample 3 after 7 days $(a, b, c)$ and14 days (d, e, $f)$

Slika 6. Uzorak 3 posle 7 dana $(a, b, c)$ i 14 dana $(d, e, f)$

In figure 6 the fungus is grown but it doesn't fill all the plate surface, both after 7 and 14 days.

If the biocide substance is mixed with Ag suspension, then the effect is better. This can be seen also from sample 4 and 5 , for both 7 and 14 days (fig. 7 and 8 ). In these figures it is not observed the fungus growth.

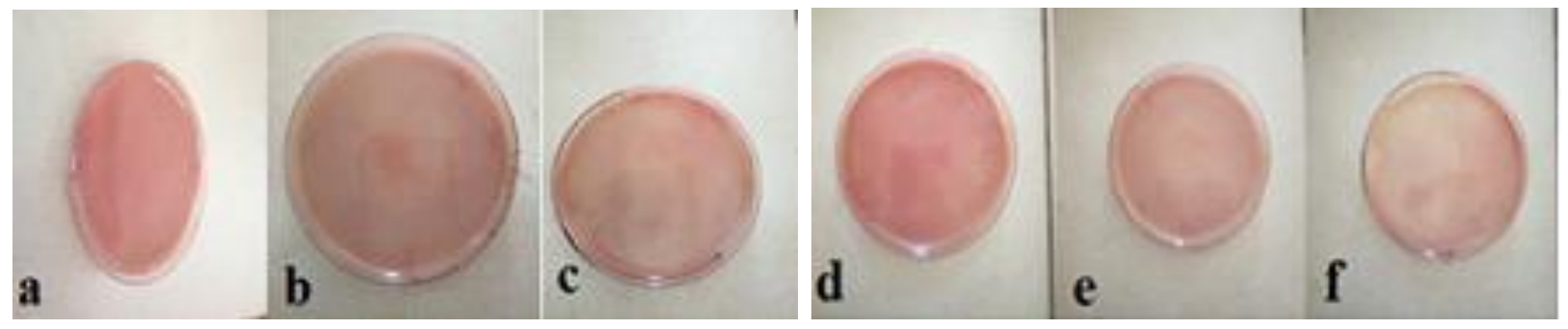

Figure 7. Sample 4 after 7 days $(a, b, c)$ and 14 days $(d, e, f)$

Slika 7. Uzorak 4 posle 7 dana $(a, b, c)$ i 14 dana $(d, e, f)$

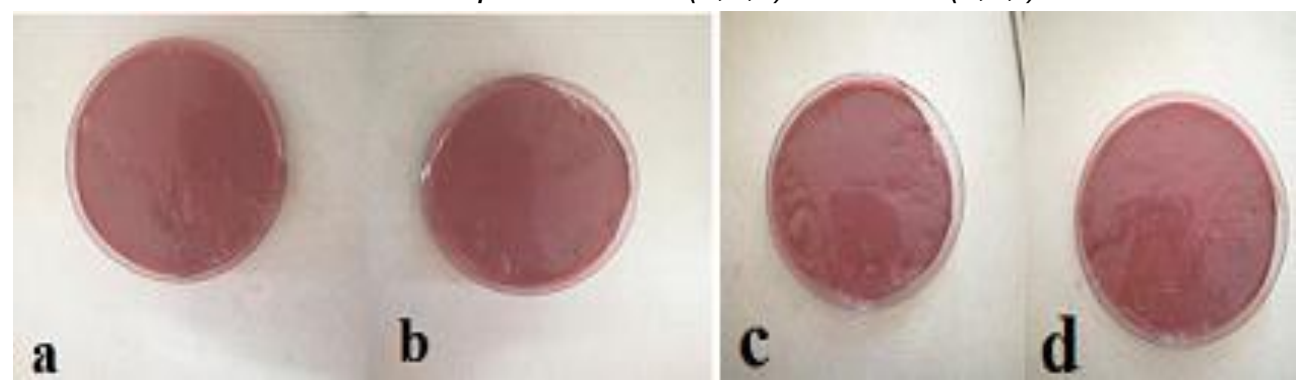

Figure 8. Sample 5 after 7 days (a, b) and 14 days (c, d)

Slika 8. Uzorak 5 posle 7 dana $(a, b)$ i 14 dana $(c, d)$ 


\section{CONCLUSION}

We investigated the antifungal efficacy of silver nanoparticles in paints of indoor applications. The biocide activity of $\mathrm{Ag}$ nanoparticles resulted better and with increasing tendence when the amount of suspension added in the sample was increased. Also if the Ag suspension is mixed with the biocide substance the effect is better. But, it is neccessary to know which is the concentration of silver suspension itself which inhibits the fungal growth without the presence of biocidal substance. The last issue will be the subject for further studies in this field.

\section{REFERENCES}

[1] J.Marku (2012) Materiale Ndërtimore Ekologjike, Tirana, p.389-419.

[2] Sh.Ishfaq, N.Ali, I.Tauseef, M.N.K.Khattak, Z.K.Shinwari, M.I.Ali (2015) Analysis of paint degradation by fungal and bacterial species, Pakistan Journal of Botany, 47(2), 753-760.

[3] J.Pulit, M.Banach, R.Szczyglowska, M.Bryk (2013) Nanosilver against fungi. Silver nanoparticles as an effective biocidal factor, The Journal of the Polish Biochemical Society and of the Committee of Biochemistry and Biophysics, 60(4), 795-798.

[4] C.Guran, A.Pica, D.Ficai, A.Ficai, C.Comanescu (2013) Antimicrobial coatings - obtaining and characterization, Indian Academy of sciences, Bulletin of Material Sciences, 36(2), 183-188.

\title{
IZVOD
}

\section{ISTRAŽIVANJE EFIKASNOSTI SUSPENZIJE NANOČESTICA SREBRA NA BOJAMA U ZATVORENOM PROSTORU}

Tokom poslednjih nekoliko decenija, nanočestice metala su privukle pažnju za široki spektar primena u različitim oblastima industrije, posebno Ag nanočestice, koje su korišćene zbog njihovih biocidnih osobina. Sa druge strane, slikarstvo se koristi još od drevnih vremena za dekoraciju, ali se površini boja nanosi šteta zbog prirodnog vremenskog uticaja, kao i rasta i aktivnosti živih organizama. Različite vrste organizama uključene su u kvarenje boje, kao što su bakterije, alge $i$ gljivice. Da bi se sprečila biodegradacija boje, korišćene su biocidne supstance, koje su vremenom izazvale probleme životne sredine i zdravlja. U ovom eksperimentalnom radu želelo se da istraži antifungalna efikasnost srebrovih nanočestica u poređenju sa trgovinskom biocidnom supstancom koja se na tržištu prodaje za zaštitu boja u unutrašnjem okruženju. Izvršena je serija mikrobioloških testova. Dobijeni rezultati pokazuju da su Ag nanočestice efikasnije u inhibiciji rasta gljivica.

Ključne reči: boje, mikološka otpornost, Ag nanočestice.

\author{
Naučni rad \\ Rad primljen: 24. 10. 2018. \\ Rad prihvaćen: 07. 11. 2018. \\ Rad je dostupan na sajtu: www.idk.org.rs/casopis
}

(C) 2018 Authors. Published by Engineering Society for Corrosion. This article is an open access article distributed under the terms and conditions of the Creative Commons Attribution 4.0 International license (https://creativecommons.org/licenses/by/4.0/) 